\title{
The Mosque Kebon Jeruk: a Portrait of Acculturation of Moslem Society in Jakarta $18^{\text {th }}$ Century
}

\author{
Parlindungan Siregar \\ Islamic History and Civilization Department \\ Syarif Hidayatullah State Islamic University \\ Jakarta, Indonesia \\ parlins@uinjkt.ac.id
}

\begin{abstract}
This research pointed out that Chinese architecture was more dominant at the Mosque Kebon Jeruk. Although, another element of architecture beside Chinese existed in it especially its material components. So, the acculturation has happened at the building of Mosque Kebon Jeruk. It was different from the assumption came from Heuken, Lombard, and Valenteen the buildings of mosques in Java had odd tiered roof form, the Mosque Kebon Jeruk had even tiered roof form, that was two. It means that the model of the roof was inspired by Chinese architecture. Departing from this building, we should say that Moslem society in Jakarta accommodated other traditions which performed by other religions and ethnic groups lived in Jakarta in their daily life. There are many methods can be used in a research, first one is the description and secondly, analysis. It means that we have to make description on all material components of the building and so that we have to analyze them. Besides, we have to use other analysis; that is morphology analysis, style analysis, technology analysis. By these analyses, we should uncover the real history of Moslem Society in Jakarta in the eighteenth century.
\end{abstract}

Keywords-acculturation; architecture; technology; analyze; material component

\section{INTRODUCTION}

The Mosque Kebon Jeruk is the first mosque built at Jalan Hayam Wuruk West Jakarta. It was constructed in 1786 by Chinese merchant or migrant from Sin Kiang, China, his name was Chau Tsien Hwu (Tamien Dossol Seng) [1]. There was no change on its construction until now except at the special material or space and shape. The renovation of the building has been done many times to protect it from damage and also to extend the wall and partition to the east, south, and west border. The old original materials at the mosque formerly still existed and some had been removed from its places because of many reasons, for example, the pulpit. The pulpit was removed to the museum Fatahillah for showing. There was also the original fan on the ceiling and pictures at the wall which had been removed to unknown place till know. However, other materials still stick at building such as pillars, ornaments, the structure of the rectangular log pieces, attached roof form, and others. So that, people can see its original construction and the mixture of architecture from the foundation to the mustaka (roof crown). The adoption of much architectural art [2] to the mosque by Tamien Dossol Seng. The building of the mosque could be said as the portrait of the acculturation of Moslems society in Jakarta at that time and is continued until now.

\section{METHOD}

This study uses qualitative method with historical and social approaches. The data is obtained through interview, observation, documentation research and study on the texts available in many libraries in Jakarta. The collected data from various sources are qualitatively analyzed during the data collection and after they were collected using historical sciences and supported with social sciences. The reconstructed ideas and opinion were examined to see their trustworthiness using triangulation method. This was used in constructing or shaping the acculturation process through the mosque.

\section{RESULT AND DISCUSSION}

\section{A. The Old Mosques in Jakarta}

There were many old mosques in Jakarta which were constructed in the eighteenth century. The first is the Mosque of al-Mansyur (1717), situated at street Sawah Lio II, Jembatan Lima, district of West Jakarta. It was built by Abdul Muhit who came from Mataram Kingdom to fight against VOC (Vereenigde Oost-Indische Compagnie) in Batavia [3]. In 1967 it was renamed al-Mansyur to memorize Kiai Haji Muhammad Mansur [4]. The second is the Mosque of Luar Batang (1736) is situated at Street Luar Batang V number 1, Penjaringan, Ancol, district of North Jakarta. It was constructed by Alhabib Husen bin Abu Bakar bin Abdullah. The third is the Mosque of Kampung Baru (1748), at Street South Bandengan, Pekojan, district of West Jakarta. It was constructed by the Moslem immigrant of India. The forth is the Mosque an-Nawier, Pekojan (1760), situated at Street Pekojan No. 79, Tambora, district of West Jakarta. It was constructed by an Arabian namely Sayid Abdullah bin Alaydrus of Hadramaut [5]. Then fifth is the Mosque Angke or al-Anwar (1761), situated at Street Tubagus Angke, Tambora, district of West Jakarta. The sixth is the Mosque 
Tambora (1761) was also protected by the constitution of cultural security since 1994. It situated at Street Tambora No. 4, Tambora, district of West Jakarta [6]. The seventh is the Mosque Krukut (1785) was one of the oldest mosques in Jakarta and constructed by Chinese Moslem and had special characteristic. Eighth, the Mosque Kebon Jeruk (1786) [7].

All of those mosques had even teirred roof form, the roofs of each mosque were sustained by four pillars. They were different from the mosques in central Java and Banten which had odd teirred roof form [8].

The Mosque Kebon Jeruk was the first mosque built alongside Street Hayam Wuruk district of West Jakarta. Generally, the mosques in the eighteenth century in Batavia were built at the riverside. The Mosque of Kebon Jeruk for instance was built at the side of river Ciliwung which the water downstream to the coast of Java Sea. The existence of the Mosque Kebon Jeruk is related to Chinese Moslems alongside that street and outside Glodok. In the period of Dutch Administration Glodok was the center of administration of the government. The fortress was built around it. After Chinese revolt in 1740, all Chinese society just allowed to stay outside the Glodok or around the site of the mosque [9], there were many Moslems society lived and stayed here, especially Chinese Moslems. It was why Tamien Dossol Seng made this building located in the outside of Glodok.

Ethnically, Chinese people had stayed in Batavia one or two centuries before J.P. Coen taking over this city in 1619 and converted its name to Batavia. Formerly it had been governed by Bantam Sultanate and the sultan named it Jayakarta. Before being taken over, the old name of Jayakarta was Sunda Kelapa. The city was governed by the Kingdom Pajajaran until 1526. Jayakarta was the name given by Fatahillah, commander in-chief of war of Sunan Gunung Jati,There were many inscriptions and historical records told that inhabitant of Batavia consisted of many ethnic groups from West Asia, East Asia, South Asia, and Archipelago. As an international harbor or port city, Jayakarta was visited by merchants and immigrants from the archipelago and foreign countries, as Kelingnese ethnic, Chinese people, Holland people, England people, and Portuguese people. Among them stayed in Jayakarta temporally one week or one month waiting for the good season going home to their country and beside them, they were many inhabitants stayed in Jayakarta permanently. In process of time there had arisen residential areas and warehouses of a colonial trading company for goods like Chinese village [10].

\section{B. The Construction of Masjid Kebon Jeruk}

There were many opinions about how this mosque was constructed. The first opinion said that there were many difficulties to tell the story how the process of this mosque was built. These difficulties beginning from the owner of the land, wide of religious land (wakaf), source of the material components, contractor, the price of materials, etc. According to Heuken and Uka Tjandrasasmita the owner of this religious land was Tuan Tsoa (the other name of Tamien Dossol Seng), the captain (leader for the China in Batavia under Dutch
Administration) between 1780 until 1797, this was based on the Dutch accounts or archives [11]. It was said that on this land there was a small prayer house (small langgar) which Tamien Dossol Seng bought and then rehabilitated and built the Mosque Kebon Jeruk. Nur Iman said it was true that the mosque was built by Tamien Dossol Seng, meanwhile, it was built on the intention (niat) and the desire of his wife, Fatimah Hwu. Another opinion said that the builder was Betawinese who built a small prayer house on 144 foursquare meter land and then the building was bought by Tamien Dossol Seng, Tamien then renovated the building.

\section{Material Components of the Mosque}

There were several material components of the Mosque Kebon Jeruk could be described and analyzed; exterior and interior components. First, at the top of the roof, there was the material we should say Mustaka (roof crown). It was made of the clay, but now it had been converted to aluminum or Zinc. Generally, old mosques in Jakarta have Mustaka as exterior decoration for the roof. This Mustaka had another function, that was to close the edge of the roof and protected it from water or rain. Second, the roof has the structure of the rectangular log pieces. Third, originally the mosque had four pillars which sustained the roof, but nowadays it has ten pillars. Fourth, there were three doors at the mosque and it had windows as a ventilation at the second floor between the two roofs. Fifth, formerly there was a minaret outside the mosque, but nowadays it had disappeared. Sixth, formerly there were also been found on the mosque large drum (beduk), ornament, two tombs with their tombstone (jirat/jurat) and gravestone, old fan on the ceiling, and drawings on the wall [12]. Last but not least veranda.

Some of those material components still exist nowadays, but partly had been disappeared. The old fan, like lotus form, might be stolen by anyone until now no one knew where it was. There were also pictures that had been removed to unknown places. There were also we found flora and fauna ornaments in the mosque. According to Chinese architectural art, the ornament was not absolute as a part of the building, may be or not it was up to the desire of the owner's building. There were on the Mosque Kebon Jeruk flora ornament consisted of climbing spiraling plant (sulur- suluran), fruit, rose leaf, and others. This climbing spiraling plant came out form the vessel that hanged on the window and so on the tomb of Fatimah Hwu behind the mosque. The climbing spiraling plant at the tomb came out from deeres mouth. There were also symmetrical geometric-shaped ornaments as empty panels, lozenge joist (woods intersecting crosswise like rhomboidal), wood trellis, and calligraphy, there were also ornaments of a pseudo-pillars frame and the hem structure.

The original ornaments that still could be seen at the mosque were at the top of the roof, that was mustaka which hollow-shaped as we saw at the Chinese roof. In 1936 the antenna lighting arrester was paired with it. Around mustaka there were moon and star ornaments. The walls and pillars ornaments were more found at the interior mosque than at the exterior mosque. The pillars stood on a structure of inclined 
hem which was found on it empty space of Longwood foursquare-form. On this long wood, foursquare- form was body pillar and on each pillar was decorated by six furrows. On the upper part of the pillars was found oblique angle and flat hem. All ornaments at north and south side of the walls had been the same. Meanwhile, the ornaments at east-side of the wall were yellow flower and leafs. Beside ornaments on the wall and pillars, there were also ornaments on the Holland floor tile. The Holland tile was more desired in Batavia which was decorated with human drawing or man-figured on it. Many Indonesian Moslems Tombs used these tegel and so at the Mosque Kebon Jeruk, although nowadays all had been removed to unknown places.

\section{Analysis of the Material Components}

How to analyze the material components of the Mosque Kebon Jeruk was very interesting working for research, especially by the archeologist. In archeological science there is four technical analysis for material remains as the cultural heritage like buildings of the mosque, palace, funeral complex, and fortress; a) morphology analysis, b) style analysis, c) technology analysis and d) contextual analysis [13]. In morphology analysis, we should focus our observation analysis to material form. For example, the mosque's roof form, it was called limasan (pyramid). We should say that pyramid style was not Jakarta's style of building, might be it was Java's style or Chinese style. Ahmad Sanusi Said, it was Chinese style. Chinese men who came to Southeast Asia brought with them their tradition and culture, especially architectural art for ritual buildings. So that, the form of the roof of the Mosque Kebon Jeruk was construction model similar with the mosques in China, particularly the mosques in Xian and Nunjie, China. One of the most architectural characteristics of China is its form of the roof of the building. The design of China traditional roof had four main types, the one was pyramid roof form. According to D.G. Kohl the use of these types started since two thousand years ago when Ching Dynasty still on the power. This pyramid Style was known in China 'Cuan Jian' and at the edge of the roof, there were tails and no ceiling under the roof [14]. The Javanese roof differed from the pattern of this mosque [15]. Thus, it can be said that it is Chinese model. This is indeed contradicted with many experts who are in the opinion that it is Javanese model.

Besides the form of the roof which was inspired by Chinese architectural art, others were the structures of the logs. The logs made of woods. The logs sustained the roof namely; a. pyramidal log (balok jurai limasan), b. the lowest log cushioned (bantalan pangkal kasau), c. the edge log cushioned (bantalan ujung kasau), d. the center of $\log$ cushioned (bantalan tengah kasau), and e. ceiling log (balok loteng). The structure of logs sustained the roof of the mosque Kebon Jeruk were the same with other logs sustained old mosques in Jakarta which constructed in the eighteenth century. Therefore, it can be said that the craftsmen formed these logs were Chinese and so were the craftsmen of the roof ridge, mustaka, windows, edge of the roof, the foundation of the building. Although the craftsman was Chinese, the materials of the mosque were archipelago in style and form like drum for calling the prayer, pulpit, etc.

There were Chinese stylish of ornaments in the mosque; the first one is the engraved pillar style. There were still four pillars which assembled to the wall. Each pillar was engraved, it forms which was said pelipit. Technically, some of the materials component of the mosque were the mixture of materials from archipelago and so do the crude material for the building.

\section{E. The Portrait of Acculturation of the Moslem Society}

In the eighteenth century, Jakarta had about 45.000 inhabitants consisted of many ethnic groups, they made assimilation and acculturation that produced children EuropeAsia or "Indo". There were also in Jakarta Japanese whom Dutch administration brought from Japan to be merchantmen and farmers in Jakarta and there was a port officer [16]. There were also in Jakarta called Mardijkers and Papanger, assimilation of Indian (Coromandel, Arakanese, Malabarness, and Bengalese) and Portuguese. Pampangos who were Jakarta inhabitants came from Luzonese, Philippine. There were also African and Malay.

As I said before that among these inhabitants of Jakarta were Moslems society. Therefore, in Jakarta (Batavia), the inhabitants consisted of many cultural and ethnic groups background, namely; Asian (India, Chinese, Arabic), European (Holland, England, Portugal) and Indonesian archipelago (Balinese, Buginese/ Makassarese, Javanese, Sundanese, Mataramese, etc. According to Hasan Ambary, their assimilation and acculturation had made the new ethnic group in Batavia, and is called them Betawise, since seventeenth century [17]. It could be said that Betawise ethnic is a new ethnic in Jakarta. It is originally the mixture of many ethnics as a result of cultural acculturation being developed since hundreds year before. Besides, Betawise is the largest culture in Jakarta consisting of various sub-culture as has been described before and the Betawises are the acculturated people. Therefore, it is true what Gow said that the acculturated people are people who have lost their original culture through long contact with other culture [18]. However, of course, anyone or researcher could tell and analyze the original from that of the result of acculturation. The mosque of Kebon Jeruk is one of the samples of that acculturation in the form of architecture.

The question now is can the architectural acculturation of the Mosque of Kebon Jeruk as it is existed in the in the form of mixed cultural mosaics be said as the portrayed of the acculturation of Moslems society in Jakarta? It is worth underlining that the process of acculturation took shape in the architectural mosaics of the mosque was run together with the acculturation of Moslems society in Jakarta at that time. In the case of the architectural mosaics of the mosque of Kebon Jeruk, the Chinese culture was dominant. It is relevant with that the characteristic of acculturation as Role Abe-Hanna [19] explained that acculturation is the process of assimilation to a different culture, typically the dominant 
one.

\section{CONCLUSION}

The research of Masjid Kebon Jeruk and the acculturation of Muslem society in Jakarta is based two theories namely architectural acculturation and anthropological acculturation. The two theories being used help the research to show that the process of acculturation in which change and continuity has been occurred since $18^{\text {th }}$ century can be observed in the case of Masjid Kebon Jeruk and the life of Moslems Society in Jakarta.

\section{REFERENCES}

[1] U. Tjandrasasmita, Arkeologi Islam Nusantara. Jakarta: Gramedia , 2009

[2] G. G. Siong, Segi-segi Peraturan Perkawinan Tjampuran. Jakarta: Jambatan, 1969.

[3] Atthiyat Gandrian (Ed.), Bangunan Cagar Budaya di Wilayah DKI Jakarta. Jakarta: Dinas Museum DKI Jakarta 1995.

[4] A. Heuken SJ. Mesjid-mesjid Tua di Jakarta. Jakarta: Yayasan Cipta Loka Caraka 2003.

[5] A. Heuken SJ. Mesjid-mesjid Tua di Jakarta. Jakarta: Yayasan Cipta Loka Caraka 2003.

[6] http://Jakarta.go.id

[7] (http://bataviase.co.id, downloaded October,5. 2010).

[8) Tugiyono dkk. Peninggalan Situs dan Bangunan Bercorak Islam di Indonesia. Jakarta: Mutiara Sumber Widya. 2001.

[9] P.D. Milone, Queen City of the East: The Metamorphosis of a Colonial Capital. Ph.D. Thesis, University of California, 1966.

[10] T. Haris. "Masjid-masjid di Dunia Melayu-Nusantara." Makalah disampaikan pada Diklat Arkeologi Keagamaan Pusdiklat Tenaga Teknis Keagamaan Badan Litabang Dan Diklat Kemenag RI. Ciputat, (2 Juni 2010).

[11] Taendiftia, E. Rahmat et all. Gado-gado Betawi: Masyarakat Betawi dan Ragam Budayanya. Jakarta:Grasindo 2002

[12] Parlindungan Siregar, Interview http://m.metrotvnews.com/video/melawan-lupa /Dkq6DWnK-masjidmasjid-saksi-sejarah-batavia-3 llupa/Dkq6DWnK-masjid-masjidsaksi-sejarah- batavia-3

[13) Pusat Penelitian Dan Pengembangan Arkeologi Nasional.Metode Penelitian Arkeologi. Jakarta:Pusat Penelitian Arkeologi Nasional. Cet. II, 2008.

[14] A. S. Hassan, "Islam Came to South East Asia From China: Evidence from Traditional Chinese Roof Design in Kampung Laut' Old Mosque, Malaysia," Canadian Social Science. Vol. 6, No. 5, ,pp. 0115, 2011.

[15] Bachtiar Fauzy, (et.al). "The Resilience of Javanese Meaning in the Architectural Acculturation of Javanese with Chinese Ethnic Houses in the Kampong of Sumber Girang and Babagan in Lasem." Journal of Basic and Applied Scientific Research www.textroad.com, 2012.

[16] P. Purbatjaraka, Shahbandar in the Archipelago.JSEAH. II. July 2, 1961.

[17] H. M. Ambary dan P. Siregar. "Sejarah Perkembangan Kota Jakarta Sejak Awal Berdirinya Hingga Abad XIX Masehi”. Laporan Penelitian Fakultas Adab dan Humaniora UIN Jakarta, 2005.

[18] Peter Gow,. "Steps towards an ethnographic theory of acculturation". Etnografia. Praktyki, Teorie, Doświadczenia, 2015.

[19] Abi-Hanna, Rola. 2014. Examining Acculturation: Can One Theory Really Explain all Experiences of Migration? International Journal for Cross- Disciplinary Subjects in Education (IJCDSE), Volume 5, Issue 4, December 2014. 